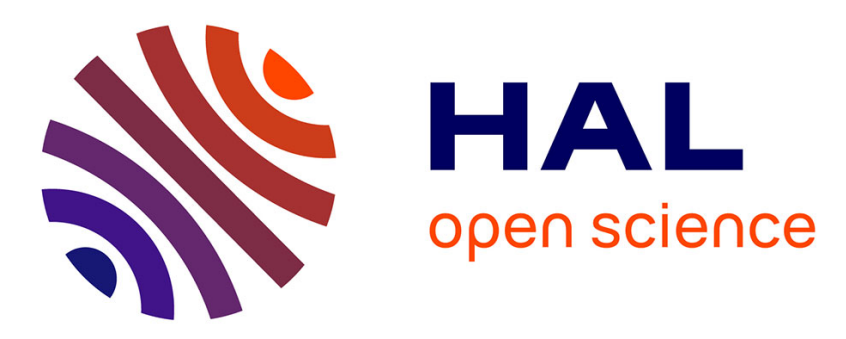

\title{
Odorant binding proteins based sniffing device for detection of tobacco
}

\author{
Khasim Cali, Emmanuel Scorsone, Krishna Persaud
}

\section{To cite this version:}

Khasim Cali, Emmanuel Scorsone, Krishna Persaud. Odorant binding proteins based sniffing device for detection of tobacco. 2017 ISOCS/IEEE International Symposium on Olfaction and Electronic Nose (ISOEN), May 2017, Montreal, Canada. pp.7968918, 10.1109/ISOEN.2017.7968918 . cea-01830784

\section{HAL Id: cea-01830784 https://hal-cea.archives-ouvertes.fr/cea-01830784}

Submitted on 4 Feb 2019

HAL is a multi-disciplinary open access archive for the deposit and dissemination of scientific research documents, whether they are published or not. The documents may come from teaching and research institutions in France or abroad, or from public or private research centers.
L'archive ouverte pluridisciplinaire HAL, est destinée au dépôt et à la diffusion de documents scientifiques de niveau recherche, publiés ou non, émanant des établissements d'enseignement et de recherche français ou étrangers, des laboratoires publics ou privés. 


\title{
ODORANT BINDING PROTEINS BASED SNIFFING DEVICE FOR DETECTION OF TOBACCO
}

\author{
${ }^{1}$ Khasim Cali, ${ }^{2}$ Emmanuel Scorsone, ${ }^{1}$ Krishna Persaud \\ ${ }^{1}$ School of Chemical Engineering and Analytical Science, The University of Manchester, UK. ${ }^{2}$ Institute \\ CEA LIST, DCSI/Diamond Sensors Group, France
}

\begin{abstract}
Affinity constants for a selection of Odorant Binding Proteins (OBPs) from mammalian and insect sources were determined toward volatile signature compounds from tobacco in the liquid phase using a fluorescent probe and competitive ligand binding. The most sensitive proteins were selected and these were immobilised on to diamond coated Surface Acoustic Wave (SAW) sensors to construct an array of eight sensors to detect tobacco volatiles. The system was then tested for its ability to detect vapours of tobacco itself as well as other markers. The results were positive, a pattern of responses across the array was observed as each sensor gave a specific response towards different analytes. To determine the stability of these OBP biosensors over time, the sensors were repeatedly exposed to pulses of saturated $\mathrm{D}(+)$-carvone vapour over three months. Little degradation was observed and these sensors were able to sensitively detect the target analytes after this period.
\end{abstract}

Index Terms - Odorant Binding Proteins, Surface Acoustic Wave Sensors, Sensor Array, Tobacco detection.

\section{INTRODUCTION}

Odorant Binding Proteins (OBPs) are small soluble proteins present in the olfactory systems of vertebrates and insects having affinity to a great number of organic molecules (odorants and pheromones). They are exceptionally stable to temperature and have a compact folding structure that makes these proteins resistant to proteolytic degradation. These characteristics are attractive to build robust, reliable and inexpensive biosensors for different applications. Recently it has been shown that Odorant Binding Proteins (OBPs) can be used as Biosensors to detect variety of volatile organic compounds [1-3]. Recombinant porcine OBPs were chemically grafted on polycrystalline diamond surfaces for biosensor development; the resulting sensors were able to detect 2, 4-DNT in vapour form [3].

The aim of this work is to develop a Sniffing device based on Odorant Binding Proteins Biosensors for the detection of tobacco. Eleven OBPs were selected for this work. Two are porcine Wild Type OBP1 (pWTOBP1) and its mutant protein $\mathrm{pF} 88 \mathrm{~W}$. Nine are from insect sources, namely wasp 1PDOMOBP1; six wild type proteins from mosquito Anopheles gambiae, AgamOBP1, AgamOBP4, AgamOBP5, AgamOBP19, AgamOBP21 and AgamOBP47; while the remaining two are mutants of AgamOBP1 developed using in silico mutagenesis and docking screening techniques, namely AgamOBP1_S82P and AgamOBP1_K93H $[1,2]$.

\section{METHODS}

The SAW readout device was from Karlsruhe Institute of Technology (KIT), Germany. Intrinsic volatile signature compounds from tobacco were selected [4]. These were 2methylpropanal, 2-butanone, ethylpyrazine and acetone. Affinity constants of the screened OBPs toward the above analytes were initially determined in the liquid phase using a fluorescent probe and competitive ligand binding $[1,2]$. The best performing proteins were selected and these were immobilised on to diamond coated Surface Acoustic Wave (SAW) sensors to form an array of eight SAW Biosensors which was then mounted on to the SAW read-out platform (SAW DEVICE) [3]. The system was then tested for its ability to detect vapours of the selected markers plus three different brands of tobacco. The tobacco brands chosen were GOLDEN VIRGINIA (Imperial Brands/UK), PALL MALL (British American Tobacco Group/UK) and HOLBORN YELLOW (Japan Tobacco International/UK). For each sample, measurements were repeated fifty times over a period of 1 week. For stability studies the sensors were repeatedly exposed to pulses of saturated D (+)carvone vapour over three months.

\section{RESULTS}

\subsection{Determination of Binding affinities in solution}

The data in Figure 1 shows that OBPs can bind to these four tobacco volatiles and with differing affinity profiles for each of the analyte. The poorly responding proteins AgamOBP5, AgamOBP21, and AgamOBP47 were eliminated and the rest were selected for incorporation into an array of SAW Biosensors. Vapours of tobacco as well as marker volatiles 
compounds were presented to the device, and results for tobacco samples are presented in Figures 2 and 3.

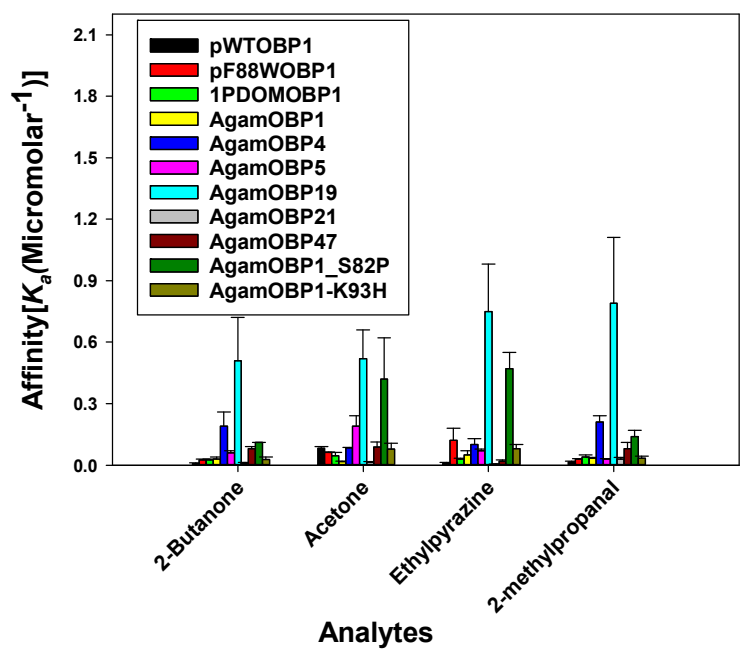

Figure 1: Affinity constants of the screened OBPs toward the selected signature volatiles of tobacco, determined in the liquid phase using a fluorescent probe and competitive ligand binding.

\subsection{Detection of tobacco by the SAW biosensor array}
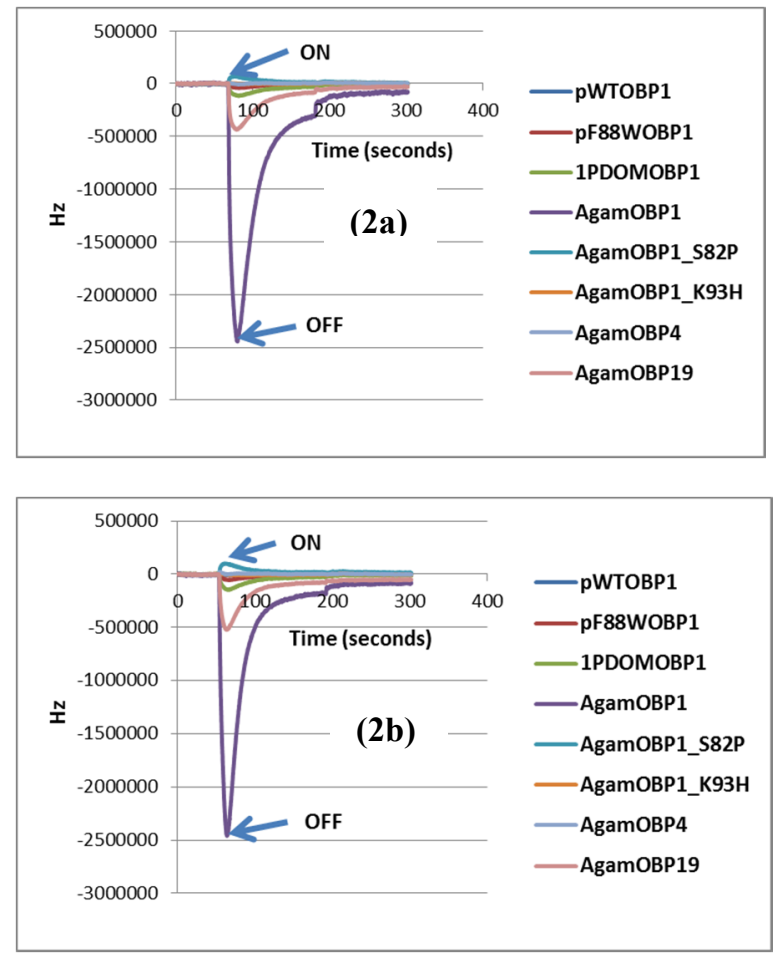

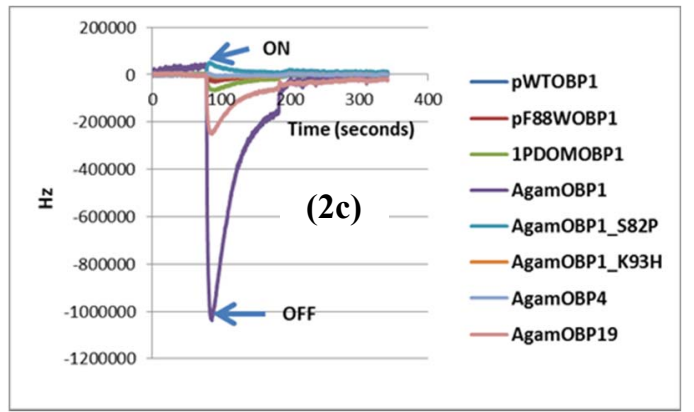

Figure 2: Raw Response of the SAW biosensor array to saturated vapour of three different brands of tobacco, (a) GOLDEN VIRGINIA (SMOOTH YELLOW), (b) PALL MALL, and (c) HOLBORN YELLOW. In (a) and (b) 'ON' $=$ Start of measurement while 'OFF' = End of measurement.
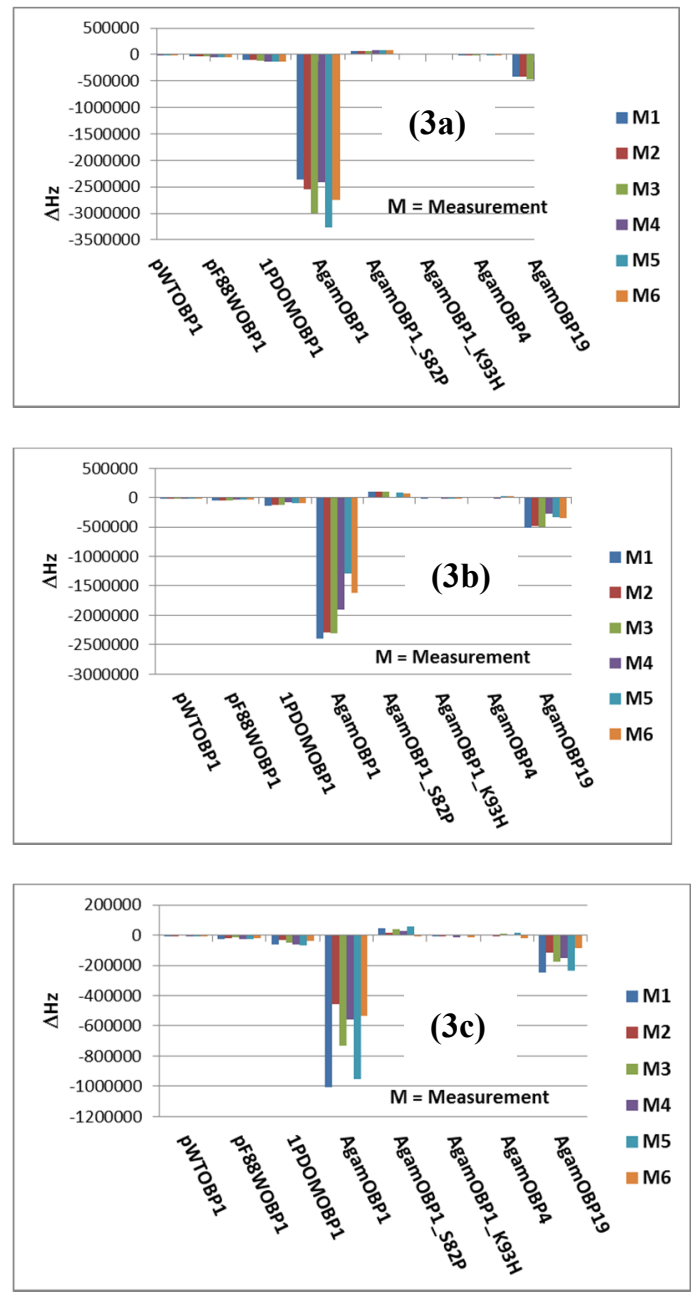

Figure 3: Repeated response of the SAW biosensor array to the saturated tobaccos vapour. For each tobacco brand, fifty measurements were taken, as an example six repetitions are shown in this figure, where (a) GOLDEN VIRGINIA (SMOOTH YELLOW), (b) PALL MALL, and (c) HOLBORN YELLOW. 


\subsection{Stability of the biosensors over time}

Despite being reported that Odorant Binding Proteins (OBPs) can be used as Biosensors to detect variety of volatile organic compounds [1-3], it was not known how stable these sensors are over time. The SAW biosensor array was exposed repeatedly to pulses of saturated $\mathrm{D}(+)$-carvone vapour over three months (Figure 4). Carvone was used as a control analyte, because several OBPs are very sensitive to this compound [5].

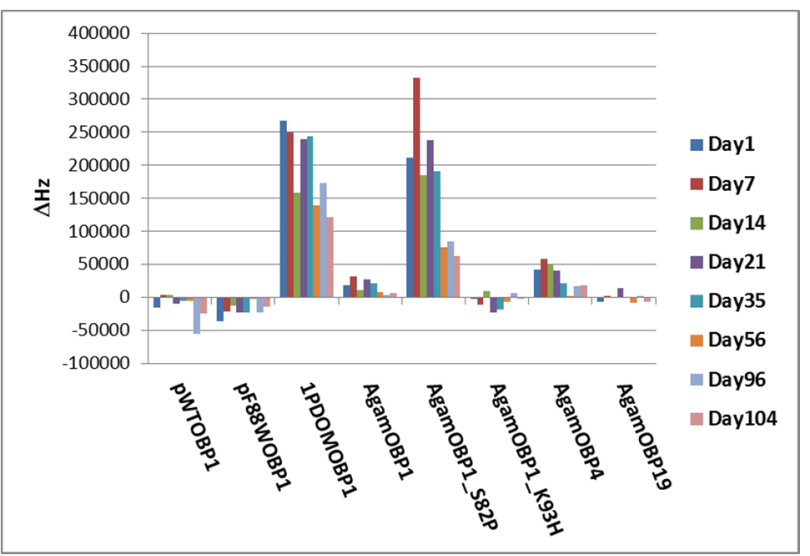

Figure 4: Biosensor stability, measured by repeated responses to $\mathrm{D}(+)$-carvone vapour measured by the SAW biosensor array over three months.

\section{DISCUSSION}

The data in Figure 2 and 3 shows that the sensors are sensitive to the tobacco vapour, each sensor displayed different response intensity to the same concentration of vapour, giving rise to a specific response pattern of the array towards the tobaccos. For example AgamOBP1 sensor is the best performing having highest sensitivity followed by AgamOBP19 while sensors pWTOBP1 and AgamOBP1_K93H have the lowest sensitivity.

The data in Figure 4 shows that the sensors retain their ability to detect analytes for more than three months. This is important and a key aspect of using these proteins as biosensors. Generally, the sensitivity of each sensor increases after sensor fabrication (Day 1 to Day 35) before achieving a stable sensitivity after some days (from day 56 to day 104). There are day to day variations in the intensity of the response - however this is largely due to the complexity of generating a consistent headspace for complex materials such as tobacco. However, what is important is that the sensors continue to operate over long periods of time and they do not fail with repeated exposure to volatile analytes.
Also the data in Figure 2, 3 and 4 shows that the biosensors may be able to recognize the target analytes selectively, the response profiles between Tobaccos (Figures 2 and 3) are quite different to that for carvone (Figure 4). For example while AgamOBP1 sensor is the best for tobacco, for carvone 1PDOMOBP1 and AgamOBP1_S82P sensors are the best performing compared to all other sensors.

\section{CONCLUSIONS}

A robust SAW Sniffing device made up of an array of Odorant Binding Proteins is reported. This opens up a new approach for detecting tobacco and other potential targets like drugs, explosives or other analytes of interest.

\section{FUTURE WORK}

The end goal is to integrate this SAW Biosensor device into a detection toolbox connected with the sampling system and supplied with operating electronics and pattern recognition software to be used for the detection of tobacco, and other potential targets for customs and security applications.

Acknowledgements: The SNIFFER project European Community (FP7/2007-2013) $\mathrm{n}^{\circ} 285203$ and project n653323 - C-BORD (H2020).

\section{REFERENCES}

[1] K. Cali, M. Bernabei, K.C. Persaud, "Development of mutant Odorant Binding Proteins (OBPs) for Security Applications: Detection of Explosives and Drugs", Chemical senses 40(3), pp. 266-267, 2015.

[2] K. Cali, M. Bernabei, K.C. Persaud, "Odorant Binding Proteins Biosensors for detection of drugs," Chemical senses 41(4), pp. 424-424, 2016.

[3] R. Manai, E. Scorsone, L. Rousseau, F. Ghassemi, M. A. Possas, G. Lissorgues, N. Tremillon, H. Ginisty, J.C. Arnault, E. Tuccori, M. Bernabei, K. Cali, K.C. Persaud, P. Bergonzo, "Grafting odorant binding proteins on diamond bio-MEMS," Biosensors \& bioelectronics 60C, pp. 311-317, 2014.

[4] W.M. Coleman, Tobacco volatiles: Gas Chromatography, Encyclopedia of Separation Science, Academic Press, Winston-Salem, NC, USA, 2000, pp. 4380-4388

[5] M.Y. Mulla, E. Tuccori, M. Magliulo, G. Lattanzi, G. Palazzo, K. Persaud, L. Torsi, "Capacitance-modulated transistor detects odorant binding protein chiral interactions", Nature Communications(6), pp. 6010, 2015. 